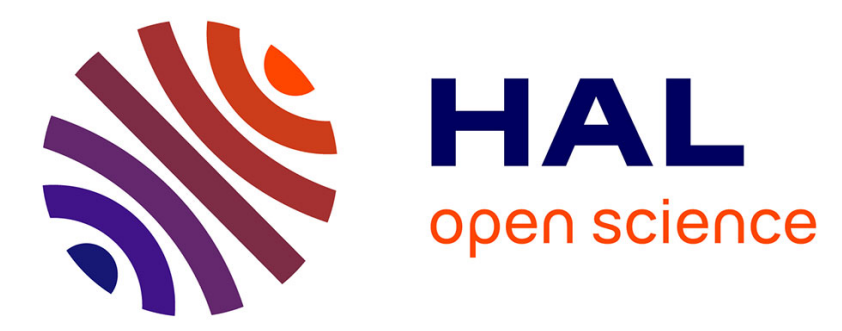

\title{
A proposal for including humus forms in the World Reference Base for Soil Resources (WRB-FAO)
}

Bernard Jabiol, Augusto Zanella, Jean-François Ponge, Giacomo Sartori, Michael Englisch, Bas van Delft, Rein de Waal, Renée-Claire Le Bayon

\section{- To cite this version:}

Bernard Jabiol, Augusto Zanella, Jean-François Ponge, Giacomo Sartori, Michael Englisch, et al.. A proposal for including humus forms in the World Reference Base for Soil Resources (WRB-FAO). Geoderma, 2013, 192, pp.286-294. 10.1016/j.geoderma.2012.08.002 . hal-00755558

\author{
HAL Id: hal-00755558 \\ https://hal.science/hal-00755558
}

Submitted on 21 Nov 2012

HAL is a multi-disciplinary open access archive for the deposit and dissemination of scientific research documents, whether they are published or not. The documents may come from teaching and research institutions in France or abroad, or from public or private research centers.
L'archive ouverte pluridisciplinaire HAL, est destinée au dépôt et à la diffusion de documents scientifiques de niveau recherche, publiés ou non, émanant des établissements d'enseignement et de recherche français ou étrangers, des laboratoires publics ou privés. 
1 A proposal for including humus forms in the World Reference Base for Soil 2 Resources (WRB-FAO)

3 Bernard Jabiol $^{\mathrm{a}}$, Augusto Zanella ${ }^{\mathrm{b}}$, Jean-François Ponge ${ }^{\mathrm{c}}$, Giacomo Sartori ${ }^{\mathrm{d}}$, Michael Englisch ${ }^{\mathrm{e}}$, Bas

$4 \quad$ van Delft ${ }^{\mathrm{f}}$, Rein de Waal ${ }^{\mathrm{f}}$, Renée-Claire Le Bayon ${ }^{\mathrm{g}}$

$5 \quad{ }^{a}$ AgroParisTech, INRA UMR 1092, Laboratoire d'Etude des Ressources Foret Bois (LERFoB), 14 rue

6 Girardet, 54042 Nancy Cedex, France

$7 \quad{ }^{b}$ University of Padua, Department of Land, Environment, Agriculture and Forestry,

8 Vialedell'Università 16, 35020 Legnaro, Italy

$9{ }^{c}$ Muséum National d'Histoire Naturelle, CNRS UMR 7179, 4 avenue du Petit-Château, 91800

10 Brunoy, France

$11{ }^{d}$ Museo Tridentino di Scienze Naturali, Via Calepina 14, 38100 Trento, Italy

$12{ }^{e}$ Bundesamtfür Wald, Department of Forest Ecology and Soil, Federal Research and Training Centre 13 for Forests, Seckendorff-Gudent-Weg 8, 1131 Vienna, Auistria

$14{ }^{f}$ Alterra, Centre for Ecosystem Studies, Environmental Sciences Group, Wageningen University and 15 Research Centre, P.O. Box 47, 6700 AA Wageningen, The Netherlands

$16{ }^{g}$ Université de Neuchâtel, Institut de Biologie, Laboratoire Sol et Végétation, Emile-Argand 11, 2009 17 Neuchâtel, Switzerland

*Corresponding author at: University of Padua, Department of Land, Environment, Agriculture and Forestry, Vialedell'Università 16, 35020 Legnaro (PD), Italy. Tel.: +39 0498272755; fax: +39 0498272686.

E-mail address:augusto.zanella@unipd.it (A. Zanella). 


\section{ABSTRACT}

The morpho-functional classification of humus forms proposed in a previous issue by Zanella and collaborators for Europe has been extended and modified, without any change in diagnostic horizons, in order to embrace a wide array of humus forms at worldwide level and to complete and make more effective the World Reference Base for Soil Resources. For that purpose 31 Humus Form Reference Groups (HFRGs) and a set of prefix and suffix qualifiers are proposed, following the rules erected for the WRB. An exhaustive classification key, respecting the principles of WRB, is suggested and examples of classification are given for some already well known humus forms.

Keywords: WRB; humus; humus classification; terrestrial humus forms; semi-terrestrial humus forms; humus diagnostic horizons; reference humus form groups; prefix and suffix qualifiers for humus forms

\section{Highlights}

A World Reference Base for Humus Forms consistent with WRB-FAO Soil Reference. > 31 Humus Form Reference Groups and a set of prefix and suffix qualifiers. > Exhaustive classification key and examples of classification.

\section{Introduction}

The last delivery of the World Reference Base for Soil Resources (IUSS Working Group WRB, 2006) updated previous texts adopted by the ISSS Council, and was proposed at the $18^{\text {th }}$ World Congress of Soil Science as the official reference for soil nomenclature. As indicated in page 1 of the abovementioned document it was considered by the entire soil scientists community as the better framework "through which existing soil classification systems could be correlated and harmonized". As in previous drafts, the humus form, i.e. the part of the topsoil which is strongly influenced by biological activities and organic matter (litter included), was only partially considered, taking into account organic layers only when their thickness was very high, and ignoring many fundamental evidences necessary for a sufficiently precise characterization of forest soils, as well as all soils not periodically ploughed. On the same year, a group of German experts proposed to adapt the most popular European and Canadian classifications of humus forms to a previous draft of WRB (Broll et al., 2006). Unfortunately this former attempt to include humus forms in the World Reference Base failed to cover the whole range of terrestrial and semiterrestrial humus forms.

Since that time, the importance given to soil/atmosphere exchanges and the carbon destocking influence of global warming raised the importance of carbon sinks, i.e. for their main part the organic component of the soil ecosystem (Harper et al., 2007). Soil changes occurred in the past through climate warming, e.g. podzols shifted to brown-earth, the driving force being the breakdown of organic layers (Willis et al., 1997), which means, from the point of view of humus form systematics, the evolution from a moder to a mull topsoil functioning (Paré et al., 2006). Climatewarming imposes a biological change to organic soil horizons, resulting in a modified carbon cycle: the carbon stocked in organic layers of moder becomes partly fixed to fine mineral particles in the newly generated organo-mineral mull structure, the remaining part being lost as $\mathrm{CO}_{2}$. Neitherthe turnover rate of soil carbon northe organic molecules in which carbon is stocked are the same when passing from moder to mull (Egli et al., 2009). While changes in soil development occur over millenaries, decrease or increase in thickness of the forest floor occurs within decades (Bernier and Ponge, 1994), the same in semi-terrestrial environments (Delarue et al., 2011). The thorough monitoring of humus forms might thus help to reveal and foresee the impact of global warming on surface-accumulated organic carbon (Paré et al., 2006; Egli et al., 2009; Ponge et al., 2011), to estimate the contribution of soil to atmospheric $\mathrm{CO}_{2}$ increase on a worldwide scale (Thum et al., 2011), and to detect changes in hydrological environment (Bullinger-Weber et al., 2007; Sevink and de Waal, 2010), soil acidification 
and eutrophication (Bernier and Ponge, 1994; Pinto et al., 2007), among many other environmental threats leading to detectable changes of humus forms within a few years.

A modern, biologically meaningful classification of humus forms has been proposed at the European level by Zanella et al. (2011a, b), encompassing a wide variety of humus forms, both in terrestrial and semi-terrestrial environments. This morpho-functional classification, which has been recently updated thanks to users' feedbacks, is the basis of our proposal to include humus form characterization in the WRB, for the sake of completing and improving this soil classification system.

\section{Architecture of the proposed classification}

Following WRB specifications, two tiers of categorical detail have been performed:31 Reference Humus Form Groups or RHFGs (tier 1), and the combination of RHFGs with prefixes and suffixes, detailing the properties of RHFGs by adding a set of uniquely defined qualifiers (tier 2).

The architecture proposed for the RHFGs is based on the same principles as WRB: "[RHFGs]are allocated to higher-level groups on the basis of diagnostic characters, i.e. factors or processes that most clearly influence thebiological formation of [humus forms]". The last published classification of humus forms elaborated by Zanella et al. (2011a, b) distinguishes 6 main morphofunctional types: Mull, Moder, Mor, Amphi, Tangel and Anmoor. These main references can be scaled along a gradient of decreasing biological activity, which is revealed by an increasing accumulation of organic remains and/or a decrease in the abundance of living animals or pellets of them (Table 1).

The rationale for combining first and second levels of previous humus form classification is to raise the scale of perception of the soil system, allowing to classify humus forms in a number of units approaching the 32 Groups of References proposed in the last version of the FAO-WRB manual (IUSS Working Group WRB, 2006).

Specific prefix and suffix qualifiers are then associated to RHFGs, allowing a wide variety of variants (second-level classification) to be defined according to biological (vegetation) and environmental (geology, climate) context. The sequence of higher-level groups of RHFGs (sets) corresponds to an equal number of steps of the proposed key of classification, in the orderof the sets reported in Table 2. Previous Enti and Para humus forms (Zanella et al. 2011a, b) are now grouped in the single RHFG of PARAHUMUS; specific qualifiers can be used for describing and classifying the numerous morphofunctional variants of these initial and/or atypical humus forms.

The key of classification of the RHFGs is based on the identification of diagnostic horizons, which are composed of basic components which are reported below.

\section{Basic components of humus forms}

Recognizable remains correspond to leaves, needles, roots, bark, twigs and wood pieces, fragmented or not, whose original organs are recognizable to the naked eye or with a 5-10 X magnifying hand lens. The humic component is formed by small and non-recognizable organic remains and/or grains of organic or organo-mineral matter, mostly comprised of animal droppings of different sizes. The humic component often takes the shape of soil aggregates, which are visible to the naked eye or with a magnifying hand lens and are classified in three types, called micro- $(<1 \mathrm{~mm})$, meso- $(1-4 \mathrm{~mm})$ and macroaggregates $(>4 \mathrm{~mm})$. Mineral particles bound to the humic component are considered as part of the humic component. On the contrary, mineral particles of different sizes, free or very weakly bound to the humic component and visible to the naked eye or with a 5-10 X magnifying hand lens, form themineral component. 
Zoogenically transformed component(indicated by 'zo' after horizon name or not indicated when implicit) is made of recognizable remains and humic components processed by animals andtransformed in animal droppings. Zoogenically transformed component may be active (currently processed by living animals) or inactive (without signs of recent animal activity).Non-zoogenically transformed component(indicated by 'noz' after horizon name) is made of recognizable remains and humic components processed by fungi or other non-faunal processes. Recognizable animal droppings are absent or not detectable in the mass by the naked eye. Fungal hyphae can be recognized as white, brown, black or yellow strands permeating the organic or organo-mineral substrates. Traces of animal activity may sometimes be detectable but are always marginal.

The structure of organo-mineral horizons can be zoogenic, being formed of micro-, meso- or macroaggregates (micro-, meso- or macrostructure, respectively) or non-zoogenic, being massive or single-grained.

The fibric component of peat is made of non-decomposed or very weakly decomposed remains of hygrophilous plants. The sapric component is made of homogeneous dark organic or organo-mineral matter comprised of well decomposed plant remains pure or partly mixed with mineral particles. Plant structures are not visible to the naked eye or with a 5-10 X magnifying hand lens.

\section{Diagnostic horizons}

As in the WRB, diagnostic horizons used for the definition of humus forms "are characterized by a combination of attributes that reflect widespread, common results of the processes of [humus form] formation or indicate specific conditions of their formation".

In order to classify a humus form it is necessary: a) to dig a little cubic pit in the soil (dimensions: $50 \mathrm{~cm}$ at least); b) to observe one of the walls of the pit; c) to identify layers, varying in composition, colour, texture, structure and thickness; d) to assign each layer to a pre-defined diagnostic horizon; e) to associate each series of superposed diagnostic horizons to one or more references using a key of classification. The minimum thickness of diagnostic horizons has been established at $3 \mathrm{~mm}$. Below this limit a horizon is considered discontinuous if clearly in patches or absent if indiscernible from other neighbouring horizons. Three types of transition between horizons are considered: very sharp transition within less than $3 \mathrm{~mm}$, sharp transition between 3 and $5 \mathrm{~mm}$ and diffuse transition if over more than $5 \mathrm{~mm}$. More detailed descriptions of diagnostic horizons and recognition criteria can be found in Zanella et al. (2011b).

\subsection{Diagnostic horizons of waterlogged topsoils}

Histic organic horizons(H horizons) are submerged and/or water-saturated for a prolonged period of the year (usually more than 6 months) or have been artificially drained (the groundwater level being kept a few decimetres under the surface level, i.e. peat meadows of the Netherlands, Belgium and northern Germany...); carbon content $20 \%$ or more (approximately $35-40 \%$ organic matter) by weight in dry samples, living roots excluded (Method: element analyzer, ISO 10694, 1995).

Following the rate of fibric and sapric components, they have been divided in three diagnostic horizons: Hf, Hm and Hs. The Hf horizon consists near entirely of almost practically unchanged plant remains(fibric component $\geq 90 \%$, sapric component $<10 \%$ horizon volume). The Hm horizon consists of moderately decomposed organic component (fibric component $10 \%$ to $70 \%$, sapric component $30 \%$ to $90 \%$ in volume). The Hs horizon is an organic horizon in an advanced stage of decomposition, with only few recognizable plant remains (sapric component $\geq 70 \%$, fibric component less than 30\% horizon volume). For the sake of RHFG identification, severalsub-types must be distinguished within Hs horizons:Hszo (meso- or macrostructured, with a high activity of soil animals, especially earthworms, mineral component less than 50\%), Hsnoz (massive, with a low activity of soil animals, humification resulting mainly from the activity of microorganisms, typical of oligotrophic environments), andHsl (with more than 50\% clay, silt or sand mineral particles). 
Histic organo-mineral horizons are called Aa (as "Anmoor"). They are dark coloured, with plastic and massive structure, either high or low base-saturated; carbon content between 7 and 20\% by weight, in dry samples, living roots excluded (Method: element analyser, ISO 10694, 1995).

Hydromorphic horizons are submerged and/or water-saturated for more than a few days but less than 6 months per year. Hydromorphic organic horizons are periodically water-saturated and show the effects of temporary anoxia; carbon content $20 \%$ or more (approximately $40 \%$ organic matter) by weight, in dry samples, living roots excluded (Method: element analyzer, ISO 10694, 1995). They are named OLg, OFg and OHg: the humic component is less than $10 \%$ in volume (roots excluded) in OLg, between 10 and 70\% in OFg and more than 70\% in OHg. Hydromorphic organomineral horizonsshow effects of temporary anoxia such as iron-mottling and oxidation/reduction colours, which cover at least $1 / 3$ of horizon depth; the carbon content being generally less than $7 \%$ by weight(Method: element analyser, ISO 10694, 1995).

\subsection{Diagnostic horizons of aerated topsoils}

Two main types of diagnostic horizons ( $\mathrm{O}$ for organic and $\mathrm{A}$ for organo-mineral) have been distinguished in aerated soils.

The OL horizon is characterized by the accumulation of leaves, needles, twigs and woody materials, most original plant organs being easily discernible to the naked eye (humic component less than $10 \%$,recognizable remains $10 \%$ or more). Suffix lettersdistinguish between neither fragmented nor transformed/discoloured leaves and/or needles (OLn) and slightly altered, sometimes only slightly fragmented leaves and/or needles (OLv).

The OF horizon is characterized by the accumulation of partly decomposed litter, mainly from transformed leaves/needles, twigs and woody materials, but without any entire plant organ (humic component from 10 to 70\%). Decomposition is mainly accomplished by soil fauna (OFzo) or cellulose-lignin decomposing fungi (OFnoz).

The $\mathbf{O H}$ horizon is characterized by an accumulation of zoogenically transformed material, mainly comprised of aged animal droppings. A large part of the original structures and materials are not discernible (humic component more than $70 \%$ ).

In some cases, above defined $\mathrm{O}$ horizons cannot be identified because of the specificity of their components, hence the need for defining more specific diagnostic horizons: lignic,rhizic and bryoic diagnostic $\mathrm{O}$ horizons $(\mathrm{OW}, \mathrm{OR}$, and $\mathrm{OM}$ horizons, respectively), are comprised of more than $75 \%$ in volume of wood remains, dead or living roots, and dead or senescent moss parts, respectively.

Different organo-mineral A horizons are identified in the field by observing the soil mass with the naked eye or with a 5-10X magnifying hand lens. Five diagnostic A horizons may be distinguished according to their structure: three zoogenic or root-structured (biomacro-, biomeso-, and biomicrostructured) according to abovementioned sizes of aggregates and two non-zoogenic or nonroot-structured(single grain, massive). Topsoil horizons weakly expressed and impossible to define (e.g. recent alluvial or aeolian deposits, horizons very poor in organic matter) are not considered to be A horizons.

\section{Key to Reference Humus Form Groups}

Step 1:Humus forms in which predominance of parent or plant material arrests or masks incipient animal activity in terrestrial or semi-terrestrial ecosystems, i.e. topsoils whose $\mathrm{O}$ (to the exception of OLn), $\mathrm{H}$ and $\mathrm{A}$ diagnostic horizons either:

\footnotetext{
- $\quad$ are absent; or
} 
- are weakly expressed and impossible to define; or

- have a total thickness $<2 \mathrm{~cm}$; or

- are lignic, rhizic or bryoic horizons over more than $75 \%$ of their total thickness: PARAHUMUS,

ORother humus forms in which faunal activities and decomposition of organic matter are well visible but are or have been strongly limited and/or influenced by anaerobic conditions

Step 2:Topsoils (organic and organo-mineral horizons) submerged and/or water saturated for more than a few months per year, of wet very base-poor soils in brook valley systems and fens and bogs, and characterized by the presence of H horizon AND:

1. Hf horizon present and thick; and

2. Hs absent

AND either

- Hm absent: FIBRIMOR,

- OR: Hm present but never thicker than Hf: MESIMOR,

\section{OR}

Step 3:Other topsoils (organic and organo-mineral horizons) submerged and/or water saturated for more than a few months per year, of wet moderately base-poor soils in brook valley systems, or baseenriched soils of drained previously base-poor fens and bogs, and characterized by the presence of $\mathrm{H}$ horizon AND:

1. Hsnoz and $\mathrm{Hm}$ always present; $\mathrm{Hf}$ possible but never thicker than $\mathrm{Hm}$ AND either

- Hf present; thickness: Hm> Hf >Hsnoz: FIBRIMODER,

- OR:Hf present; thickness: Hm>Hsnoz>Hf: MESIMODER,

- OR:Hf absent, thickness: Hm>Hsnoz: HUMIMODER,

- OR:• Hf absent, thickness: Hsnoz>Hm: SAPRIMODER,

\section{OR}

Step 4:Other topsoils (organic and organo-mineral horizons) submerged and/or water saturated for more than a few months per year, of moderately moist base-poor soils in brook valley systems or baserich soils in half-drained fens and bogs, and characterized by the presence of an H horizon AND:

1. Hszo horizon presentand dominant in thickness; and

2. Hf and $\mathrm{Hm}$ thinner than $\mathrm{Hszo}$ within the control section (first $40 \mathrm{~cm}$ below the surface), Hsl possible

AND either

- Hf absent, Hm possible: HUMIAMPHI,

- OR:Hf present, Hm possible; thickness: Hszo >Hf $>\mathrm{Hm}$ : MESIAMPHI, 
- OR:Hf present, Hm absent; thickness: Hszo>Hf: FIBRIAMPHI,

OR

Step 5:Other topsoils (organic and organo-mineral horizons) submerged and/or water saturated for more than a few months per year, or organic and drained,of moist base-rich soils in brook valley systems or fens and bogs (large extended systems characterized by a dominant process of sedimentation, large floodplains), and characterized by the presence of Aa or H horizon(s) AND:

243 1. Hf or Hm never present within the control section; and

$2442 . \quad$ Hszo or Hsl present at the top of the profile; and

3. Hsnoz possible but thinner than Hszo

AND either

- Hsl present and thicker than Aa: LIMIMULL,

- OR:Hszo present and thicker than Hsnoz: SAPRIMULL,

OR

250

251

252

253

254

Step 6:Other topsoils (organic and organo-mineral horizons) submerged and/or water saturated for more than a few months per year, of wet base-rich soils or soils enriched by base-rich groundwater in brook valley systems (small rivers, brooks, small streams and floodplains, not in dynamic floods or inundations with fast currents), and characterized by the presence of Aa or $\mathrm{H}$ horizon(s) AND:

1. Aa organo-mineral horizon present and dominant;and

2. HszoandHsl possible but never thicker than Aa

$$
\text { AND either }
$$

- H absent: EUANMOOR,

- OR: Hszo present and thinner than Aa: SAPRIANMOOR,

- OR: Hsl present and thinner than Aa: LIMIANMOOR,

\section{OR}

Step 7:Other topsoils, never submerged and/or water saturated, or only a few weeks per year,in which faunal activities and decomposition of organic matter are strongly limited by mountain climate (low temperature, continental distribution of rainfall, higher in summer) on calcareous hard substrate and warmer aspect, AND having:

1. Organic zoogenic horizons present and thick $(\mathrm{OFzo}+\mathrm{OH}>5 \mathrm{~cm})$; and

2. Hard limestone and/or dolomite rock fragments at the bottom of the humus profile; and

3. Cold climate (subalpine or upper mountain belts); and

4. OFnoz absent; and

5. A massive or single grain or biomesostructured present and thin (thickness $<1 / 2 \mathrm{OH}$ ), with $\mathrm{pH}_{\text {water }} \geq 5$

AND either 
- Sharp transition between $\mathrm{OH}$ horizon and Anoz horizon, DYSTANGEL,

- OR: no sharp transition between OH and A horizons, EUTANGEL,

\section{OR}

Step 8: Other topsoils, never submerged and/or water saturated, or only for a few days per year, in which faunal activities and decomposition of organic matter are strongly limited by cold and/or acid conditions,AND having:

1. never A biomeso or biomacro;

AND three of the following:

- presence of $\mathrm{OFnoz}$

- very sharp $(<3 \mathrm{~mm})$ transition of $\mathrm{O}$ to $\mathrm{A}, \mathrm{AE}$ or $\mathrm{E}$ horizons

- pHwater of $\mathrm{E}$ or $\mathrm{AE}$ or A horizon $<4.5$;

- A absent, or A biomicro, or A massive, or A single grain,

AND either:

- OFnoz continuous, $\mathrm{OH}$ absent,A biomicro absent, EUMOR,

- OR: OFnoz continuous, OH present and continuous, A biomicro possible, HUMIMOR,

- OR: OFnoz discontinuous and OH present and continuous, A biomicro possible HEMIMOR

\section{OR}

Step 9: Other topsoils, never submerged and/or water saturated, or only for a few days per year, in which biological activities and decomposition of organic matter are moderately limited by low temperature and/or acidity of the parent material, ANDhaving:

1. $\quad \mathrm{OH}$ horizon present (even if sometimes discontinuous); and

2. OFnoz absent; and

3. Biomacro- and biomesostructured A horizons absent; and

4. Biomicrostructured, or massive, or single grain A horizon present, and one of the following:

- No sharp transition OH/A horizon (transition < $3 \mathrm{~mm}$ ); or

- pHwater of the A horizon $<5$

AND either:

- OH horizon continuous and $\geq 1 \mathrm{~cm}$, DYSMODER,

- OR: OH horizon continuous and $<1 \mathrm{~cm}$, EUMODER,

- OR: OH horizon discontinuous or in pocket, HEMIMODER,

\section{OR}

Step 10:Other topsoils, never submerged and/or water saturated, or only a few days per year, in which faunal activities and decomposition of organic matter are strongly influenced by seasonally contrasted climate conditions (Mediterranean or sub-Mediterranean distribution of rainfall, i.e. higher in spring and autumn, very low during summer,causing drought stress especially in the topsoil) AND having: 
307 1. OFnoz horizonabsent; and

308 2. Thickness of A horizon $>1 / 2$ that of $\mathrm{OH}$ horizon;

$309 \quad$ AND either

$3103 . \quad \mathrm{OH}$ and biomesostructured A horizons present; and one of the following:

311 - Living earthworms (or freshly deposited earthworm faeces) in the Ahorizon; or

312 - Diffuse transition between A and OH horizons; or

313 - $\mathrm{pH}_{\text {water }}$ of the $\mathrm{A}$ horizon $\geq 5$;

314 4. AND either:

- OH horizon $\geq 3 \mathrm{~cm}$, PACHYAMPHI,

- OR: OH horizon < $3 \mathrm{~cm}$, EUMESOAMPHI,

OR

3. $\mathrm{OH}$ and biomacrostructured A horizons present; and one of the following:

- Living earthworms (or freshly deposited earthworm faeces) in the A horizon; or

- Sharp transition between $\mathrm{OH}$ and A horizons; or

- $\mathrm{pHwater}$ of the A horizon $\geq 5$

4. AND either:

- OH horizon $<1 \mathrm{~cm}$, LEPTOAMPHI,

- OR: OH horizon $\geq 1 \mathrm{~cm}$, EUMACROAMPHI,

\section{OR}

Step 11:Other topsoils, never submerged and/or water saturated, or only a few days per year, in which faunal activities and decomposition of organic matter are weakly or not limited by harsh environmental conditions, AND having:

1. OH horizon absent; and

2. Biomacrostructured A horizon present; or

2. Biomesostructured A horizon present and at least two of the following:

- Presence in the A horizon of living earthworms or their casts, except in frozen or desiccated soil;

- Presence of a very sharp transition $(<3 \mathrm{~mm})$ between organic and organo-mineral horizons;

- pHwater of the A horizon > 5

AND either:

- OF horizon present and continuous, DYSMULL,

- OF horizon missing or discontinuous and OLv horizon continuous and thick, OLIGOMULL, 
- OF horizon missing and OLv horizon present but discontinuous, MESOMULL,

- OF and OLv horizons missing, EUMULL

\section{Prefix and suffix qualifiers}

Qualifiers are used for the second level of humus form classification, exactly in the same manner as for soils (IUSS Working Group WRB, 2006). Many prefix and suffix qualifiers used for soil classification are also used for humus form classification (Table 3). However, most of them are here attributed to the "A horizon" instead to a defined part of the soil profile(ex. calcaric, dystric, clayic, skeletic...). Other qualifiers are specific to particular humus forms (ex. hyperrhizic, hyperbryoic...).

\section{Some examples}

Loranger (2001) and Loranger et al. (2003) described a humus form, called amphimull according to classification by Brêthes et al. (1995), in Caribbean semi-evergreen secondary forests on pure hard calcareous substrate (tropical rendzina). This humus form was characterized by the presence of $\mathrm{O}$ horizons (OL $4 \mathrm{~cm}, \mathrm{OF} 2 \mathrm{~cm}, \mathrm{OH} 1.5 \mathrm{~cm}$ ) overlying a biomacrostructured A horizon. According to our proposal it can be called EUMACROAMPHI, with the prefix haplic indicating that neithertypically associated nor intergrade qualifiers apply, and the suffix rendzic indicating the pedogenetic context, hence haplic EUMACROAMPHI (rendzic). In a nearby forest plantation on deep vertisol a humus formwith contrasting characters was called Eumull according to abovementioned literature. It was characterized by a thin $(1 \mathrm{~cm})$ OLn horizon overlying directly a deep biomacrostructured A horizon. According to our proposal this is a EUMULL (name unchanged) with the suffix eutric acknowledging for the base-saturated A horizon (IUSS Working Group WRB, 2006), hence haplic EUMULL (eutric).

In a quite climatic (temperate) and geographic context (western Europe), Gillet and Ponge (2002) described a humus form, which they called mor, in a poplar plantation strongly polluted by heavy metals ( $\mathrm{Zn}$ up to $40,000 \mathrm{mg} \cdot \mathrm{kg}^{-1}$ ) where poplar failed and was replaced by thrift (Armeria maritima) vegetation. Plant remains accumulate in a context from which faunal and bacterial activities were excluded, resulting in thick $\mathrm{O}$ horizons $(\mathrm{OL}, 1 \mathrm{~cm}$, OFnoz, $9 \mathrm{~cm}$ ) lying directly on industrial waste products. Such a humus form can be called haplic EUMOR (spolic).

Bullinger-Weber et al. (2007) described several types of humus forms in alluvial soils of the Swiss Alps, with strong changes in thickness and nature of diagnostic horizons according to riverbank successional status. The youngest profile (under willow) was described as a Eumull, according the abovementioned French classification. It exhibited characteristic features on initial soils in an otherwise calcareous context. It was characterized by the scarce presence of a very thin (when present) OLv horizon, overlying a thin $(1 \mathrm{~cm})$ weakly differentiated organo-mineral horizon without any traces of animal activity visible to the naked eye and with a very poor content in organic matter, overlying in turn on sandy alluvial deposits. Given the impossibility to discern trends in the formation of diagnostic horizons (although faunal investigations on earthworms and enchytraeids testimony for incipient mull formation), such a humus form, without any structured $\mathrm{O}$ and $\mathrm{A}$ horizons, could be called PARAHUMUS, with hyperskeletic, hyperarenic as prefixes and fluvic and calcaric as suffixes, hence hyperskeletic hyperarenic PARAHUMUS (fluvic, calcaric).

Hiller et al. (2005) described soils and humus forms in Swiss alpine tundra ecosystems, following for humus forms the British Colombian classification by Green et al. (1993). Outside snow beds, at alpine elevation $(2800 \mathrm{~m})$ they found a humus form they called Rhizic Mullmoder. It was characterized by the following sequence from surface to depthaccording to the here presented nomenclature of diagnostic horizons: an OLv horizon $(5-6 \mathrm{~cm})$, then an OFzo horizon with abundant 
roots $(3-5 \mathrm{~cm})$, then when present an $\mathrm{OH}$ horizon $(0-3 \mathrm{~cm})$ overlying with a wavy transition a singlegrain A horizon. According to the present classification, such a humus form could be named HEMIMODER (because of the discontinuous $\mathrm{OH}$ horizon and the gradual transition from $\mathrm{O}$ horizons to a single-grain A horizon), with rhizic as suffix, hence haplic HEMIMODER (rhizic).

Fons et al. (1998) described a new humus form, called 'Lamimoder', which was observed to occur in trembling aspen boreal forests and more generally in circumboreal broadleaf forests. It was characterized by a thick OF horizon in which nonzoogenic (OFnoz) horizons, with a dense root mat of aspen, were thicker than zoogenic (OFzo) horizons, overlying a continuous $\mathrm{OH}$ horizon. Unfortunately, no details were given of the transition of $\mathrm{O}$ to $\mathrm{A}$ (or E) horizons. According to our proposal, and supposing that the transition was abrupt $(<3 \mathrm{~mm})$, this humus form could be called haplic HUMIMOR (rhizic).

To the date of our proposal to include humus forms in the FAO-WRB soil classification, we suggest assigning to a "pedon" two names, corresponding to a humus profile established on a soil profile. Examples (using some just reported humus forms on a most probable soil reference) are given below:

haplicEUMACROAMPHI (rendzic) on rendzic LEPTOSOL

haplicEUMACROAMPHI (rendzic) on VERTISOL

haplicEUMOR (spolic) on TECHNOSOLL

hyperskeletic hyperarenic PARAHUMUS (fluvic, calcaric) on FLUVISOL

haplicHEMIMODER (rhizic) on folic UMBRISOL

haplicHUMIMOR (rhizic) on enticPODZOL

\section{Conclusion and perspectives}

Including the European morpho-functional classification of humus forms (Zanella et al., 2011a, b) in the World Reference Base for Soil Resources would allow to profitably identify and characterize forest and other unploughed soils, embracing a wide variety of terrestrial and semiterrestrial humus forms (Dudal, 2003). This integration, that reflects the present state of our knowledge (Blum and Laker, 2003), is based on the flexibility given by the adjunction of prefix and suffix qualifiers to a set of 31 reference groups. Tests made with a large array of humus forms described in Europe as well as in tropical, temperate, mountain and boreal biomes showed that the proposed classification is able to be used worldwide. However, it remains to check its applicability where estimating the nature and the thickness of diagnostic horizons and of basic components in the field is tricky. Since some time is necessary for a given biological process to result in the formation of a given horizon (for instance the formation of a biomacrostructured A horizon needs the existence of a stable population of soil-dwelling earthworms, i.e. at least several consecutive years without population collapse), cases where this requirement cannot be fulfilled will make the identification of diagnostic horizons rather difficult if even impossible. This is what is currently happening due to the expansion of earthworm populations for several causes such as global warming, forecast by Ponge et al. (2011) and confirmed by personal observations (J.F. Ponge), or the invasion of North-American terrestrial ecosystems by earthworm species of European origin (Frelich et al., 2006). In both cases profound changes in humus forms occur, increasing vertical and horizontal heterogeneity: horizons are perturbed in the topsoil and abrupt changes may appear in the forest floor at the scale of a few meters without any link to litterfall amount and quality (Hale et al., 2005). Diagnostic features of directional changes in humus forms (whether passing from mull-forming to moder-forming processes or the reverse, as an example) would be welcome, if we want not only to describe but also to forecast humus form dynamics. Other difficulties may lie in the temporary (or incipient) nature of some environments, such as glacier moraines, river banks, seashore dunes and many others. In this case, and for the same 
reasons, time needed for the formation of horizons is lacking. The creation of reference groups without any definite horizons such as PARAHUMUS, may contribute to solve this problem, but incipient biological processes which may (or not) be conducive to the formation of identifiable horizons are not sufficiently known.

\section{Acknowledgements}

Authors acknowledge the contribution of all members of the Humus Group which participated to the construction of the morpho-functional classification of humus form at the European level.

\section{References}

Bernier, N., Ponge, J.F., 1994.Humus form dynamics during the sylvogenetic cycle in a mountain spruce forest. Soil Biology and Biochemistry 26, 183-220.

Blum, W.E.H., Laker, M.C., 2003. Soil classification and soil research.In: Eswaran, H., Rice, T., Ahrens, R., Stewart, B.A. (Eds.), Soil Classification. CRC Press, Boca Raton.

Brêthes, A., Brun, J.J., Jabiol, B., Ponge, J.F., Toutain, F., 1995. Classification of forest humus forms: a French proposal. Annales des Sciences Forestières 52, 535-546.

Broll, G., Brauckmann, H.J., Overesch, M., Junge, B., Erber, C., Milbert, G., Baize, D., Nachtergaele, F., 2006. Topsoil characterization: recommendations for revision and expansion of the FAOdraft (1998) with emphasis on humus forms and biological features. Journal of Plant Nutrition and Soil Science 169, 453-461.

Bullinger-Weber, G., Le Bayon, R.C., Guenat, C., Gobat, J.M., 2007. Influence of some physicochemical and biological parameters on soil structure for soil structure formation in alluvial soils. European Journal of Soil Biology 43, 57-70.

Delarue, F., Laggoun-Défarge, F., Buttler, A., Gogo, S., Jassey, V.E.J., Disnar, J.R., 2011.Effects of short-term ecosystem experimental warming on water-extractable organic matter in an ombrotrophicSphagnumpeatland (Le Forbonnet, France).Organic Geochemistry 42, 10161024.

Dudal, R., 2003. How good is our soil classification? In: Eswaran, H., Rice, T., Ahrens, R., Stewart, B.A.(Eds.), Soil Classification. CRC Press, Boca Raton.

Egli, M., Sartori, G., Mirabella, A., Favilli, F., Giaccai, D., Delbos, E., 2009. Effect of north and south exposure on organic matter in high Alpine soils.Geoderma 149, 124-136.

Frelich, L.E., Hale, C.M., Scheu, S., Holdsworth, A.R., Heneghan, L., Bohlen, P.J., Reich, P.B., 2006.Earthworm invasion into previously earthworm-free temperate and boreal forests. Biological Invasions 8:1235-1245.

Green, R.N., Trowbridge, R.L., Klinka, K., 1993. Towards a taxonomic classification of humus forms. Forest Science Monographs 29, 1-49.

Hale, C.M., Frelich, L.E., Reich, P.B., Pastor, J., 2005. Effects of European earthworm invasion on soil characteristics in northern hardwood forests of Minnesota, USA. Ecosystems 8, 911-927.

Harper, R.J., Beck, A.C., Ritson, P., Hill, M.J., Mitchell, C.D., Barrett, D.J., Smettem, K.R.J., Mann, S.S., 2007. The potential of greenhouse sinks to underwrite improved land management. Ecological Engineering 29, 329-341. 
ISO 10694, 1995.Soil Quality.Determination of Organic and Total Carbon after Dry Combustion (Elementary Analysis).International Organization for Standardization, Geneva.

IUSS Working Group WRB, 2006. World Reference Base for Soil Resources 2006: a Framework for International Classification, Correlation and Communication, $2^{\text {nd }}$ edition. Food and Agriculture Organization of the United Nations, Rome.

Loranger, G., 2001. Formes d'humus originales dans une forêt tropicale semi-décidue de la Guadeloupe. Comptes-Rendus de l'Académie des Sciences de Paris, Sciences de la Vie 324, 725-732.

Loranger, G., Ponge, J.F., Lavelle, P., Humus forms in two secondary semi-evergreen tropical forests. European Journal of Soil Science 54, 17-24.

Paré, D., Boutin, R., Larocque, G.R., Raulier, F., 2006. Effect of temperature on soil organic matter decomposition in three forest biomes of eastern Canada.Canadian Journal of Soil Science 86, 247-256.

Pinto, P.E., Gégout, J.C., Hervé, J.C., Dhôte, J.F., 2007. Changes in environmental controls on the growth of Abies alba Mill. In the Vosges Mountains, north-eastern France, during the 20th century. Global Ecology and Biogeography 16, 472-484.

Ponge, J.F., Jabiol, B., Gégout, J.C., 2011. Geology and climate conditions affect more humus forms than forest canopies at large scale in temperate forests. Geoderma 162, 187-195.

Sevink, J.; de Waal, R.W., 2010.Soil and humus development in driftsands.In: Fanta, J. and Siepel, H. (Eds.), Inland Drift Sand Landscapes. KNNV Publishing, Zeist.

Thum, T., Raisanen, P., Sevanto, S., Tuomi, M., Reick, C., Vesala, T., Raddatz, T., Aalto, T., Jarvinen, H., Altimir, N.,Pilegaard, K., Nagy, Z., Rambal, S.,Liski, J., 2011.Soil carbon model alternatives for ECHAM5/JSBACH climate model: Evaluation and impacts on global carbon cycle estimates. Journal of Geophysical Research, Biogeosciences 116, G02028.

Willis, K.J., Braun, M., Sümegi, P., Tóth, A., 1997.Doessoil change cause vegetation change or vice versa?A temporal perpective from Hungary. Ecology 78, 740-750.

Zanella, A., Jabiol, B., Ponge, J.F., Sartori, G., de Waal, R., Van Delft, B., Graefe, U., Cools, N., Katzensteiner, K., Hager, H., Englisch, M., 2011a. A European morpho-functional classification of humus forms. Geoderma 164, 138-145.

Zanella, A., Jabiol, B., Ponge, J.F., Sartori, G., de Waal, R., Van Delft, B., Graefe, U., Cools, N., Katzensteiner, K., Hager, H., Englisch, M., Brêthes, A., Broll, G., Gobat, J.M., Brun, J.J., Milbert, G., Kolb, E., Wolf, U., Frizzera, L., Galvan, P., Koli, R., Baritz, R., Kemmers, R., Vacca, A., Serra, G., Banas, D., Garlato, A., Chersich, S., Klimo, E., Langohr, R., 2011b. European Humus Forms Reference Base [http://hal.archivesouvertes.fr/docs/00/56/17/95/PDF/Humus Forms ERB 31 01 2011.pdf]. 
Table 1: Humus forms in different ecosystems and along a gradient of decreasing biological activity. The wellknown terrestrial gradient "Mull-Moder-Mor" is visible on the row "Terrestrial on acid substrate". Notice that four main morpho-functional types (Mull, Moder, Amphi and Mor) can be Terrestrial and Semi-terrestrial as well, contrary to Tangel and Anmoor which are only Terrestrial and Semi-terrestrial, respectively. On the other hand, detailed morpho-functional types (second level of classification) have different names even if they belong to the same main morpho-functional type.According to this principle, Eumull, Mesomull, Oligomull and Dysmull are Terrestrial humus forms, while Limimull and Saprimull are Semi-terrestrial humus forms. Information about biodegradation rates is maintained in the name of second level units.

\begin{tabular}{|c|c|c|c|c|c|c|}
\hline \multirow[t]{2}{*}{ Ecosystem } & & & Biologic & $\begin{array}{l}\text { activity } \\
\text { rate }\end{array}$ & & \\
\hline & $\begin{array}{l}\text { Main morpho- } \\
\text { functional type }\end{array}$ & $\begin{array}{c}\text { Detailed } \\
\text { morpho- } \\
\text { functional types }\end{array}$ & $\begin{array}{l}\text { Main morpho- } \\
\text { functional type }\end{array}$ & $\begin{array}{c}\text { Detailed } \\
\text { morpho- } \\
\text { functional types }\end{array}$ & $\begin{array}{l}\text { Main morpho- } \\
\text { functional type }\end{array}$ & $\begin{array}{c}\text { Detailed } \\
\text { morpho- } \\
\text { functional types }\end{array}$ \\
\hline $\begin{array}{l}\text { Terrestrial: } \\
\text { on calcareous } \\
\text { substrate }\end{array}$ & \multirow[t]{2}{*}{ Mull } & \multirow{2}{*}{$\begin{array}{l}\text { Eumull } \\
\text { Mesomull } \\
\text { Oligomull } \\
\text { Dysmull }\end{array}$} & Amphi & $\begin{array}{l}\text { Leptoamphi } \\
\text { Eumacroamphi } \\
\text { Eumesoamphi } \\
\text { Pachyamphi }\end{array}$ & Tangel & $\begin{array}{l}\text { Eutangel } \\
\text { Dystangel }\end{array}$ \\
\hline $\begin{array}{c}\text { Terrestrial: } \\
\text { on acid substrate }\end{array}$ & & & Moder & $\begin{array}{l}\text { Hemimoder } \\
\text { Eumoder } \\
\text { Dysmoder }\end{array}$ & Mor & $\begin{array}{l}\text { Hemimor } \\
\text { Humimor } \\
\text { Eumor }\end{array}$ \\
\hline $\begin{array}{c}\text { Small Semi- } \\
\text { terrestrial: } \\
\text { brook valleys, } \\
\text { little rivers... }\end{array}$ & Anmoor & $\begin{array}{l}\text { Euanmoor } \\
\text { Saprianmoor } \\
\text { Limianmoor }\end{array}$ & $\begin{array}{c}\text { Amphi } \\
\text { or }\end{array}$ & $\begin{array}{l}\text { Humiamphi } \\
\text { Mesiamphi } \\
\text { Fibriamphi } \\
\text { or }\end{array}$ & Mor & \\
\hline $\begin{array}{l}\text { Large Semi- } \\
\text { terrestrial: } \\
\text { floodplains, fens } \\
\text { and bogs... }\end{array}$ & Mull & $\begin{array}{l}\text { Limimull } \\
\text { Saprimull }\end{array}$ & & $\begin{array}{l}\text { Humimoder } \\
\text { Mesimoder } \\
\text { Fibrimoder }\end{array}$ & & \\
\hline
\end{tabular}


Table 2.Factors or processes that most clearly influence the biological formation of the main Sets of Humus

520 Form Reference Groups.

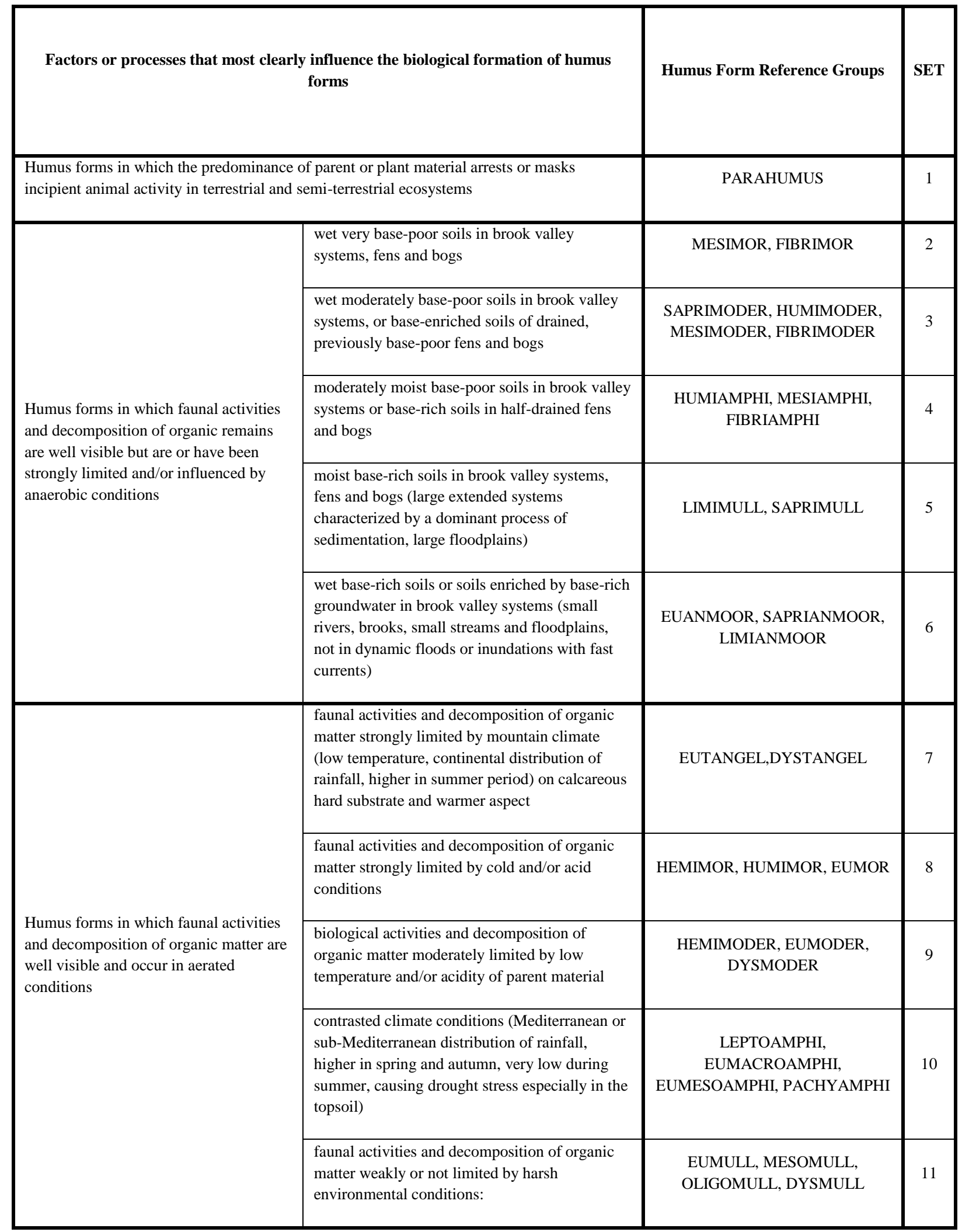


523

524

525

526

Table 3. Prefix and suffix qualifiers used for the definition of humus forms. Qualifiers already used for the definition of soils (IUSS Working Group WRB, 2006) are indicated. Vocabulary refers to the present article or (*) to IUSS Working Group WRB (2006).

\begin{tabular}{|c|c|c|c|}
\hline PREFIX & SUFFIX & WRB 2006 & DEFINITION, new or adapted for humus forms \\
\hline hyperlignic & & no & $\begin{array}{l}\text { having an OW horizon of more than } 75 \% \text { of the thickness of combined diagnostic horizons (Parahumus } \\
\text { only) }\end{array}$ \\
\hline hyperrhizic & & no & $\begin{array}{l}\text { having an OR horizon of more than 75\% of the thickness of combined diagnostic horizons (Parahumus } \\
\text { only) }\end{array}$ \\
\hline \multirow[t]{6}{*}{ hyperbryoic } & & no & $\begin{array}{l}\text { having an OM horizon of more than 75\% of the thickness of combined diagnostic horizons (Parahumus } \\
\text { only) }\end{array}$ \\
\hline & lignic & yes (modified) & $\begin{array}{l}\text { having an OW horizon between } 25 \text { and } 75 \% \text { of the thickness of combined diagnostic horizons or having } \\
\text { more than } 25 \% \text { of wood remains in the total volume }\end{array}$ \\
\hline & rhizic & no & $\begin{array}{l}\text { having an OR horizon between } 25 \text { and } 75 \% \text { of the thickness of combined diagnostic horizons or having } \\
\text { more than } 25 \% \text { of dead or living roots in the total volume }\end{array}$ \\
\hline & bryoic & no & $\begin{array}{l}\text { having an OM horizon between } 25 \text { and } 75 \% \text { of the thickness of combined diagnostic horizons or having } \\
\text { more than } 25 \% \text { of dead or senescent moss parts in the total volume }\end{array}$ \\
\hline & folic & yes & whose $\mathrm{OH}$ or $\mathrm{H}$ horizon is $>10 \mathrm{~cm}$ \\
\hline & ombric & yes & having a histic* horizon saturated predominantly with rainwater \\
\hline \multirow[t]{2}{*}{ stagnic } & & yes & having reducing conditions and $\mathrm{OLg}, \mathrm{OFg}, \mathrm{OHg}$ and/or Ag horizon with stagnic* colour patterns \\
\hline & gleyic & yes & lying directly on a horizon with gleyic* colour patterns \\
\hline floatic & & yes & having organic material floating on water \\
\hline epihistic & & no & having both $[(\mathrm{OL}, \mathrm{OF}, \mathrm{OH}) \mathrm{g}$ and/or $\mathrm{Ag}]$ and histic $(\mathrm{H}$ or $\mathrm{Aa})$ horizons \\
\hline \multirow[t]{11}{*}{$\begin{array}{l}\text { fluvic (also for } \\
\text { lakes) }\end{array}$} & & yes & whose A horizon or first mineral horizon comes with evidence from fluvic* material \\
\hline & novic & yes & $\begin{array}{l}\text { having above the } \mathrm{O} \text { horizon, a layer with recent sediments (new material }<1 \mathrm{y} \text {.), } 3 \mathrm{~mm} \text { or more and less } \\
\text { than } 2 \mathrm{~cm} \text { thick }\end{array}$ \\
\hline & sodic & yes & having $15 \%$ or more exchangeable $\mathrm{Na}$ plus $\mathrm{Mg}$ on the exchange complex in the A horizon \\
\hline & alcalic & yes & having a $\mathrm{pH}$ (1:1 in water) of 8.5 in the $\mathrm{A}$ horizon \\
\hline & calcaric & yes & whose A horizon is calcaric* material \\
\hline & hypereutric & yes & having a base saturation (by $1 \mathrm{M} \mathrm{NH} 4 \mathrm{OAc}$ ) of $80 \%$ or more in the A horizon \\
\hline & eutric & yes & having a base saturation (by $1 \mathrm{M} \mathrm{NH} 4 \mathrm{OAc}$ ) of $50 \%$ or more in the A horizon \\
\hline & dystric & yes & having a base saturation (by $1 \mathrm{M} \mathrm{NH} 4 \mathrm{OAc}$ ) of less than $50 \%$ in the $\mathrm{A}$ horizon \\
\hline & hyperdystric & yes & having a base saturation (by $1 \mathrm{M} \mathrm{NH} 4 \mathrm{OAc}$ ) of less than $20 \%$ in the $\mathrm{A}$ horizon \\
\hline & clayic & yes & having a texture of clay in the A horizon \\
\hline & arenic & yes & having a loamy fine sand or coarser texture in the A horizon \\
\hline \multirow[t]{2}{*}{ hyperarenic } & & no & $\begin{array}{l}\text { having a loamy fine sand or coarser texture within } 2 \mathrm{~cm} \text { of the soil surface without an } \mathrm{A} \text { horizon under } \\
\text { OLn (Parahumus only) }\end{array}$ \\
\hline & lithic & yes & having continuous rock directly under the A horizon and within $10 \mathrm{~cm}$ of the soil surface \\
\hline \multirow[t]{2}{*}{ hyperlithic } & & no & having continuous rock under OLn and within $2 \mathrm{~cm}$ of the soil surface (Parahumus only) \\
\hline & skeletic & yes & $\begin{array}{l}\text { having } 40 \% \text { by volume or more of gravel or other coarse fragments in the A horizon and within } 10 \mathrm{~cm} \\
\text { of the soil surface }\end{array}$ \\
\hline \multirow[t]{10}{*}{ hyperskeletic } & & yes & containing less than $20 \%$ by volume of fine earth within $2 \mathrm{~cm}$ of the soil surface \\
\hline & hyperhumic & yes & having an organic carbon content of $5 \%$ or more in the fine earth fraction to a depth of $20 \mathrm{~cm}$ or more \\
\hline & rendzic & yes & whose $\mathrm{A}$ horizon is a mollic* horizon that contains $40 \%$ or more calcium carbonate equivalent \\
\hline & andic & yes & whose A horizon has andic* properties \\
\hline & salic & yes (prefix) & whose A horizon is a salic* horizon \\
\hline & albic & yes & with $\mathrm{O}$ horizons lying directly on an albic* horizon \\
\hline & hortic & yes & whose A horizon is an hortic* horizon \\
\hline & terric & yes & whose $\mathrm{A}$ horizon is a terric* horizon \\
\hline & technic & yes & having $10 \%$ or more artefacts in combined diagnostic horizons \\
\hline & urbic & yes & $\begin{array}{l}\text { having } 25 \% \text { or more artefacts, containing } 35 \% \text { or more of rubble and refuse of human settlements, in } \\
\text { combined diagnostic horizons }\end{array}$ \\
\hline hyperurbic & & no & $\begin{array}{l}\text { having } 75 \% \text { or more artefacts, containing } 35 \% \text { or more of rubble and refuse of human settlements, in } \\
\text { combined diagnostic horizons }\end{array}$ \\
\hline
\end{tabular}




\begin{tabular}{|c|c|c|c|}
\hline & spolic & yes & $\begin{array}{l}\text { having } 25 \% \text { or more artefacts, containing } 35 \% \text { or more industrial waste, in combined diagnostic } \\
\text { horizons }\end{array}$ \\
\hline \multirow[t]{2}{*}{ hyperspolic } & & no & $\begin{array}{l}\text { having } 75 \% \text { or more artefacts, containing } 35 \% \text { or more industrial waste, in combined diagnostic } \\
\text { horizons }\end{array}$ \\
\hline & garbic & yes & $\begin{array}{l}\text { having } 25 \% \text { or more artefacts, containing } 35 \% \text { or more organic waste materials, in combined diagnostic } \\
\text { horizons }\end{array}$ \\
\hline \multirow[t]{3}{*}{ hypergarbic } & & no & $\begin{array}{l}\text { having } 75 \% \text { or more artefacts, containing } 35 \% \text { or more organic waste materials, in combined diagnostic } \\
\text { horizons }\end{array}$ \\
\hline & erodic & no & $\begin{array}{l}\text { having only remnants of diagnostic horizons, due to mechanical perturbation (erosion, waterlogging, } \\
\text { action of boars or other macro mammals ...) }\end{array}$ \\
\hline & plaggic & no & $\begin{array}{l}\text { having } 25 \% \text { or more artefacts, containing } 35 \% \text { or more "plaggen" (Dutch name for a mixture of heather } \\
\text { humus, manure and sand used for raising sandy soils around settlements), in combined diagnostic } \\
\text { horizons }\end{array}$ \\
\hline hyperplaggic & & no & $\begin{array}{l}\text { having } 75 \% \text { or more artefacts, containing } 35 \% \text { or more "plaggen" (see plaggic), in combined diagnostic } \\
\text { horizons }\end{array}$ \\
\hline haplic & & yes & closes the prefix qualifier list indicating that neither typically associated nor intergrade qualifiers apply \\
\hline
\end{tabular}

527 
Table 4.List of qualifiers for humus forms and their possible addition to the 31 Humus Form Reference Groups."?" means possible but not to present knowledge. The new prefix qualifiers with "hyper" (Table 3: hyperlignic, hyperrhizioc, hyperbryoic, hyperurbic, hyperspilichypergarbic and hyperplagggic) apply to PARAHUMUS only, like "hyperlignic", here indicated as an example.

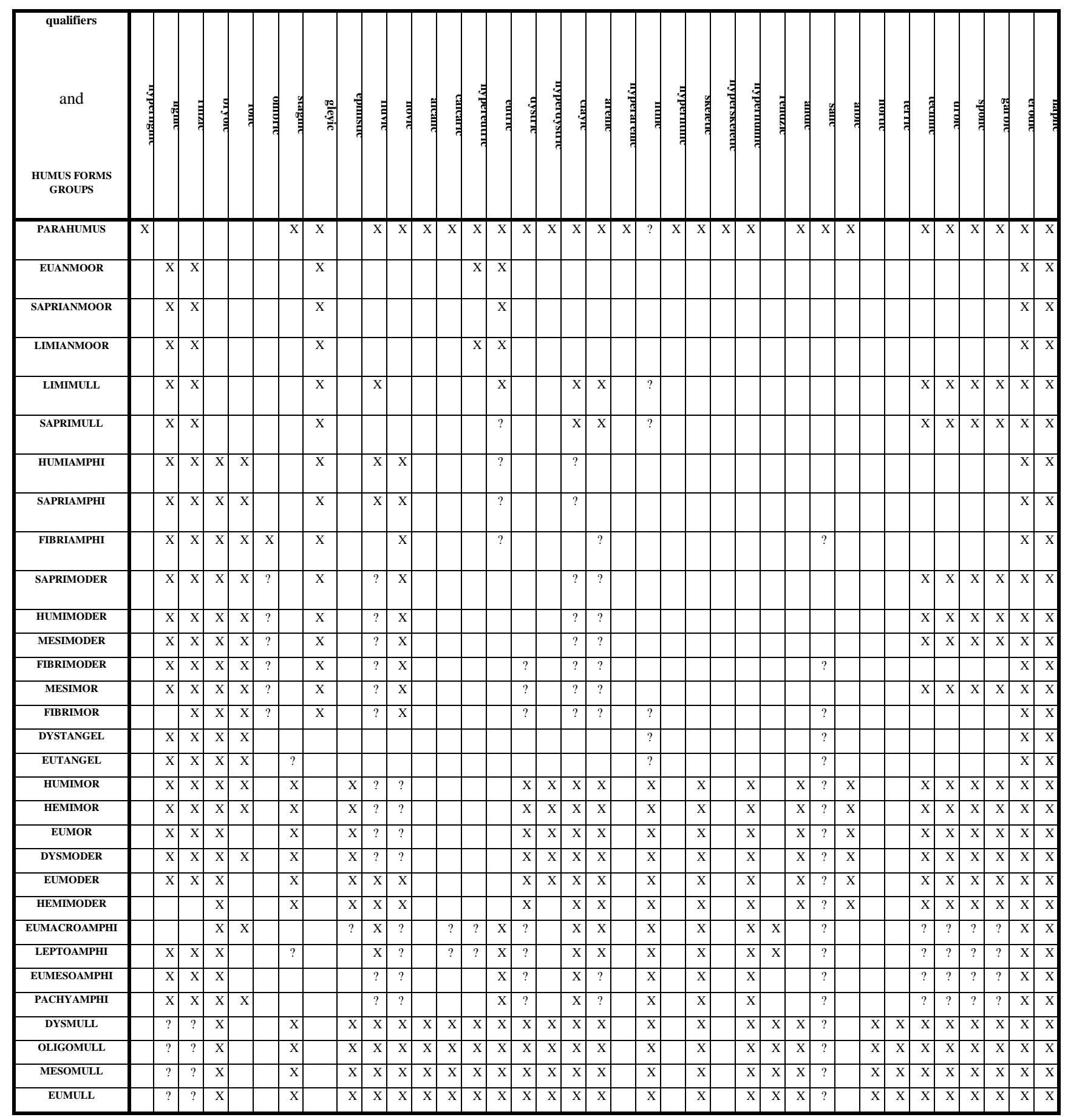

